\title{
Reconciling Safety and Fairness in Global Agri-Food Standardization
}

\author{
Yuichiro Amekawa \\ Institute of Biological Sciences, University of Malaya, Kuala Lumpur, Malaysia \\ Email: yamiko7@hotmail.com
}

Received September $16^{\text {th }}$, 2012; revised October 22 ${ }^{\text {nd }}, 2012$; accepted November $7^{\text {th }}, 2012$

\begin{abstract}
Private food safety standards have recently emerged as a dynamic power in the global value chan. Good agricultural practices (GAP) is one such standard currently gaining popularity as a prominent field-level food quality assurance system. Achieving private GAP certification, most notably of GlobalGAP, is a difficult option for low income producers in the Global South due to the high costs required for necessary investments and certification. This paper critically analyzes the ethical implications of private food safety standards in light of three theoretical perspectives from environmental sociology: ecological modernization, risk society, and eco-socialism. It then examines the potential of public GAP schemes currently emerging in the Global South for reconciling safety and fairness in global agri-food standardization. It is suggested that the expansion of producer participation in public GAP program be regulated by gradual improvements in the state capacity of resource mobilization for auditing and extension institutions.
\end{abstract}

Keywords: Global Agri-Food Standardization; Food Safety; Fairness; Good Agricultural Practices; Public Gap Standards

\section{Introduction}

Private standards have recently emerged as a dynamic power in global agri-food systems. On the supply side, the rapid growth of Northern retailers in the global value chain and their submergence in the food industry of the Global South have entailed the development of standards as tools of coordination of supply chains that standardize product requirements over geographically diverse suppliers (Temu \& Marwa, 2007). On the demand side, growing consumer awareness about food safety in the Global North, mediated by the shifts of their preferences from packaged goods to various fresh products, has led major retailers in the North to develop various voluntary food safety standards (Busch \& Bain, 2004).

Green Revolution and genetic engineering biotechnology represent a well referenced pair of instrumental power that global agro-industries have shaped and relied on, thereby having received poignant criticisms from the opponents. The rapid development of agri-food standards in the global value chain has not received as much public attention, perhaps due to the less ostensible nature of institutional innovations and the still limited scale impact within the conventional regime. It is noteworthy, however, that they have steadily been challenging and transforming the mode of production, systems of distribution, and patterns of consumption in various parts of the globe.

This paper explores the issues of contradiction between food safety and fairness and its reconciliation, with considerations of private and public GAP standards. The paper is structured as follows. Section two reflects on the emerging gap between enhancing safety assurance and declining social inclusion in private food safety standardization. Section three discusses ethical implications of private food safety standards. Section four seeks ways to reconcile safety and fairness in global agri-food standardization by focusing on the case of the public approach to food safety standardization. The last section is devoted to conclusions.

\section{Emerging Gap between Safety and Fairness in Private Food Safety Standardization}

Now consider GlobalGAP - the pioneering and most prestigeious field-level private food safety standards of "Good Agricultural Practices” (GAP). Originally named EurepGAP, this private standard has been developed since the late 1990s by the Euro-Retailers Produce Working Group (EUREP), a consortium of major European retailers. This initiative embraces a variety of food safety codes of conduct with regard to consumer food safety, hygiene, labor conditions, animal welfare, as well as environmental management on the farmland. The standard protocol initially focused on fresh fruit and vegetables (FFV), and later covered other crops, aquaculture, and livestock, allowing for certification of integrated management systems. By December 2010, GlobalGAP has embraced 102,586 certified growers in 108 countries and 122 independent accredited certification bodies worldwide (GlobalGAP, 2010). It has become a global model of field-level food safety standards with which countries and industries aspire to harmonize existing standards (Okello \& Swinton, 2007).

\section{Dumping and Exclusion of Smallholder Producers in the Global Value Chain}

While GlobalGAP has played innovative roles to improve and ensure the quality of global food safety assurance system, there have been emerging concerns raised about its distributive effects on the upstream supply chain. Stringent compliance with GlobalGAP (and other harmonized national GAP programmes benchmarked to GlobalGAP such as ChileGAP and 
MexicoGAP) may demand costly investments for upstream suppliers. These investments relate to technical training for innovative production and hygiene practices, variable inputs such as safer yet more costly pesticides, structures such as grading sheds, charcoal coolers, disposal pits, and pesticide storage units, as well as periodical certification and accreditation. Consequently, lead buyers in the North rely on economies of scale by sourcing products from larger and more resourceful exporters and growers. By forcing third party certification on upstream suppliers, they are able to minimize transaction costs and financial liability while enhancing credibility of their production practices (Okello \& Swinton, 2007).

This process of consolidation and concentration of large enterprises in GlobalGAP and harmonized programmes leads to the social cost of marginalizing, removing, or excluding smaller exporters and growers in the Global South. By way of illustration, the vegetable export sector in Kenya has been reported to show that from September 2003 to mid-2006, 60\% of the surveyed 9342 small-scale farmers who had been part of the GlobalGAP operations were dropped by their export company or withdrawn from compliance schemes (Graffham, Karehu, \& MacGregor, 2007).

In Uganda, the number of small-scale farmers exporting fruit and vegetables declined from about 2150 in 2005 to about 1260 in 2006 reportedly due to increasing airfreight charges and stringent requirements of GlobalGAP (Graffham et al., 2007). In addition, insufficiency of revenues due to the lack of price premium mechanisms in GAP programmes poses another major economic risk for small-scale producers participating in those programmes. The overall absence of a price premium to support small-scale growers raises questions about their incentives to participate in GAP standards, given that they tend to be disadvantaged in covering additional costs of facility accommodation, auditing, and certification.

\section{Technical Drawbacks in the Production Process}

Another risk for small-scale producers arises from the technical mismatch between the management measures that private GAP programmes stipulate and those actually needed to deal with ecological problems occurring in the field. Graffham and MacGregor (2007) provide evidence from Zambia that exporters would not buy peas from the small farm sector because the management and controls offered by GlobalGAP were inadequate to control the pest problems of the high-risk yet highreturn crop. It was therefore imperative for the exporter to introduce innovative company technologies in the GlobalGAP scheme. Yet the existing level of financial costs that were already too high for such additional investments made it prohibitive. Consequently, exporters did not choose to purchase peas from the small farm sector, which would be to the disadvantage of the farmers producing it.

\section{Ethical Implications of Private Food Safety Standards}

To gain an informed understanding of the basic characteristics and potential effects of private food safety certification schemes such as GlobalGAP on the Global South, it may be illuminating to engage a broader ethical discussion within a theoretical purview of ecological analysis in social theory. Three perspectives from environmental sociology, i.e., ecolo- gical modernization, risk society, and eco-socialism, can be employed to highlight the ethical implications of private food safety standardization for modernity, ecology, stratification, and social change.

\section{In Light of Ecological Modernization Theory}

Originally devised by German sociologist Joseph Huber in the 1980s, ecological modernization theory has been gaining increasing prominence in northern Europe and elsewhere in various fields of environmental policy and social science. Emanated from Huber's conviction that contemporary environmental problems should inescapably be resolved by "superindustrialization," this theory envisages an explicit vision of hyper-modernity: science, industry, and state institutions can promote emancipation of ecology by means of cleaner technology and improved eco-efficiencies generating competitive advantages and a sustained economic growth. Hence, seeing the ecological challenge "not as a crisis but as an opportunity" (Blowers, 1997: p. 847), the theory presumes the following set of prescriptive trajectories: first, the industry should come ready to assure its ecological responsibility by investing in developing cleaner, more efficient, and less resource intensive technologies. Second, the state should adopt more decentralized, flexible, and consensual styles of governance to render the private sector more efficient and effective. Third, the state should adopt more innovative policy measures (e.g., environmental taxes, voluntary agreements). Fourth, preventive socio-technological approaches should replace traditional curative ones from the design stage of ecological innovation (Cohen, 1997; Mol \& Sonnenfeld, 2000; Murphy, 2000).

The underlying conception and governance of private food safety measures such as GlobalGAP appears to be consonant with a notion of ecological modernization as follows. Northern major retailers advancing in the Global South have benefited from the opportunity structure created in the neo-liberal milieu of economic liberalization beginning in the early 1990s. Some governments in the Global South opened their market along the GATT/WTO lines, attracted foreign direct investments, and implemented less interventionist measures. Private standards have come to serve as a competitive instrument for advancing transnational supermarket chains by virtue of the regulation systems that are systematically based on precautionary principles, thereby ensuring advantages that consumers entertain over traditional suppliers. In practice, the major retailers seeks to incorporate into the standards environmentally less harmful agricultural technologies and practices such as integrated pest management and integrated crop management, in concert with management efficient and cost effective specifications for product and delivery attributes (Henson \& Reardon, 2005). They can ascertain even more efficiency and quality assurance by rendering certification and accreditation producers' liability by mandating them third-party certification (Graffham \& MacGregor, 2007).

On grounds of these congenialities, an ecological modernizationist view might subscribe to a moral economy perspective of private food safety standardization: more technologically and organizationally sophisticated ecological transactions towards improved food safety, quality management, and environmental protection through enforcement of food safety standards would allow major retailers to capture more export markets and profits. Accordingly, such private food safety measures can act as a sturdy shield that not only protects the health and safety of 
Northern consumers, but also guards Northern retailers and exporting nations from the possibility of a health crisis that could threaten the global reputation and marketability of their export products (Henson \& Reardon, 2005).

\section{In Light of Risk Society Theory}

Ulrich Beck, the German sociologist who has developed risk society theory, argues that the risk society arises as the second phase of modernity in which the aging of the industrial paradigm in the first modernity inevitably leads to catastrophic risks of global destruction overshadowed by ecological uncertainty (e.g., nuclear explosion, climate change). The new risks pertain to the unintended consequences of the very technoeconomic processes born out in the faith of "progress" to conquer nature (e.g., hunger, natural disaster)—the paradox Beck has called "boomerang" (Beck, 1992). The inherently uncertain nature of these new risks compels experts to disagree over the judgment of what is "safe" (Henson \& Reardon, 2005).

Unlike ecological modernization theory, therefore, risk society theory downplays the role of modern industrial institutions for solving ecological problems. The theory instead emphasizes the role of "sub-politics" - the core notion of Beck's evolutionary vision of "reflexive modernization" toward a more sustainable and just society. Beck places considerable emphasis on the role of the lay public (i.e., individual citizens, social movement organizations) in leading sub-politics through activities such as democratization of technical knowledge, boycotting campaigns, and so on. As an ecological issue is spatially boundless by nature, so it develops sub-politics beyond geographic boundaries by voluntary initiatives of "cosmopolitan" allies called "globalization from below." These global coalitions are in opposition to the so-called "globalization from above," the centralizing political economic forces under neo-liberalism (e.g., supranational institutions and agreements, multinational corporations) that primarily engage in bringing various resources and the environment under their control (Beck, 1992).

The political maneuver of risk society perspective highlights the barely direct, if not absent, mode of commitment by civic movement components to the design and enforcement of socio-ecological criteria in private food safety measures. These measures have been developed as preemptive corporate measures aimed to avert litigious disputes with the general public, with various preventive devices placed in concert with traceability methods applied ex post facto. Hence, GlobalGAP is acting as a quasi-minimum quality standard for GAPs that is primarily concerned with the condition of access to the market for suppliers (Cordon, Giraud-Héraud, \& Soler, 2005). In this respect, these standards are clearly different from the case of alternative trading and certification initiatives (e.g., international organic and fair trade) that are driven more by civicsector involvements. Albeit with the potential risk for appropriation by multinational corporate interests (Murray \& Raynolds, 2000), the latter initiatives place more weight on filtering socially construed values such as fairness and/or environmental conservation into product demand (Barham, 2002).

A reflexive modernization opinion may likewise buttress secondary measures in private food safety measures such as GlobalGAP that could represent consumer support for egalitarian safe food production (e.g., price premiums, "special equity" labeling). This is unlikely to materialize without an external stimulus, however, because these measures are driven primarily by corporate profit motives rationally tied to consumers' selfinterests in personal health which bypass other altruistic concerns. In addition, the overall techno-administrative approach in private food safety measures, in particular the techno-scientific objectivism of third party certification, further attests to the prevalence of less democratic risk management governmentality (Hatanaka, Bain, \& Busch, 2005). Thereby, experts play predominant roles in determining problems and solutions in relative isolation from super-industrial interventions. Overall, the weak civic-sector leverage in the making and operation of private food safety measures is paralleled by ecological modernization theory's “relatively little emphasis on the role of radical environmental groups or new social movements (NSMs) in making possible ecological modernization processes” (Buttel, 2000: p. 62).

\section{In Light of Eco-Socialism}

Eco-socialism may offer yet another critical perspective on the potential effects of private food safety measures on the Global South. Despite with its broad constituency, eco-socialist discourse focuses on a socio-ecological critique of capitalism, in many cases made from an explicit de-modernization perspective. It postulates that capital's unlimited pursuit of wealth accumulation leads to an escalation of resource exploitation, wasteful material consumption, and environmental destruction, possibly to such a catastrophic degree that the very survival of humankind is threatened. At the center of the environmental degradation and associated social injustices lie the relations of domination by the capitalist class over labor and nature (not the technological imperatives of industrialization as ecological modernization and risk society theories uphold) (Löwy, 2002).

Eco-socialism thus seeks revolutionary struggles over the hegemony of capital by an alliance between the reds (labor movements) and the greens (environmental movements) toward a new civilization - a classless and ecologically defensible society. The painful lesson of the first epoch socialist model (e.g., the Soviet regime) enlightens us that democratic worker and community control over the production of use values (goods required for the satisfaction of human needs) and the use of ecologically sound production systems (e.g., solar energy) is key to actualize such a radical systemic change (Burkett, 2002).

Eco-socialism claims incompatibility with the ecological modernizationist vision of "green (or sustainable) capitalism" (Fisher \& Freudenburg, 2001). The naturalistic, egalitarian, and utopian views of eco-socialism break with the ecological modernizationist emphasis on norms such as eco-efficiency, competition, growth, and profit. As such, an authentic eco-socialist view may hold the notion of green capitalism as just another productivism of a revisionist sort veiling some essentially capitalistic contradictions in its ecological guise.

Such an eco-socialist line of critique can be captured to serve the ethical analysis of private food safety measures, possibly on three dimensions. First, ecological systems deployed in private food safety measures such as GlobalGAP may end up selfdefeating for capital. James O’Connor (1998) formulated the thesis of the second contradiction of capitalism, which posits that in addition to the first contradiction (examined by Marx) between productive forces (capital's accumulation imperatives) and production relations (capital and labor), capitalism gives rise to the second contradiction between forces of production and the conditions of production (nature, labor power, and 
socio-infrastructural organization). The second contradiction, O'Connor argues, points to capital's destruction and erosion of its productive base beginning with the natural environment.

This eco-socialist critique of the self-destructive nature of capitalism may arrest an immanent feature of the corporate approach to sustainable agriculture which the prominent agroecologist Miguel Altieri calls "input substitution.” This approach refers to a production strategy that "only emphasizes environmentally benign alternatives to agrochemical inputs, without challenging either the monoculture structure or the dependence on off-farm inputs that characterize agricultural systems" (Rosset \& Altieri, 1997: p. 283).

The production structure anchored in some large estate agriculture in GlobalGAP schemes may be regarded as the variant of input-substitution involving the use of environmentally benign inputs (e.g., bio-agents, compost). It typically involves features such as use of extensive land, large machinery and agrochemicals, as well as dependence on fossil fuels, which all characterize modern industrial agriculture. Such structural biases of ecological simplification and genetic homogeneity that characterize it run the risk of pest resistance and outbreak (Rosset \& Altieri, 1997). The continual capitalist exploitation of soil, water, and the air through more deliberate use of chemical fertilizers manufactured in factories signify the lasting significance of Marx's theory of "metabolic rift" (developed by John Foster and others) - the deep-seated break in the necessary metabolic cycle between nature and society (Foster, 2000). These systemic traits are much less characteristic of subsistence-oriented systems prevalent over much of the Global South that involve small-scale, highly diversified, resource conserving, and ecologically sound enterprises. If such an ecological disaster takes place with certain severity and scale, it suggests a systemic maltreatment of and by capital itself.

Second, the concept of the second contradiction of capitalism directs attention to the contradiction with labor. As exemplified by GlobalGAP, introduction of many private food safety measures has resulted in a rapid exclusion of small-scale producers. Such unfairness rests on firm material bases, such as skyrocketing requirements for new investments and recurrent costs in support of consumer food safety assurance, coupled with the absence of subsidies and price premium mechanisms to support small-scale production. An eco-socialist approach may be positioned to view these circumstances as the product of a serious institutional flaw of contemporary capitalism rather than a mere amalgam of material shortcomings. This viewpoint echoes Blowers' critique of ecological modernization in that it "focuses on the economic and technological dimensions; it is largely innocent of the social context of change and the ethical issues that are raised” (1997: p. 854), in the sense that capital fails to develop overarching institutional systems that could address and resolve the social contradictions that it creates and to maintain social trust in its own enterprises.

Finally, the global agri-food standardization promoted by major capitalist interests and the consequent switchover of upstream production to larger farms highlights the monopolization of wealth and power by the Northern minority over the Global South. Since the early 1980s, Allan Schnaiberg has developed a neo-Marxist notion of 'treadmill of production.' In the treadmill metaphor, capitalism is perceived as a gigantic production and accumulation machine that seeks global economic expansion for the profit of elites; this monstrous machine is, along the way, steadily bringing the earth's carrying capacity to its limits through exploitation of resources and labor as well as environmental destruction. This notion provides eco-socialist thinkers with a powerful critique of the ecological modernizationist assumption: greening of capitalism is not the predominant trend but applies primarily to the experiences of a limited number of advanced industrial economies (i.e., Germany, Japan, The Netherlands, and Nordic countries; Cohen, 2006; Langhelle, 2000; Mol \& Sonnenfeld, 2000) or even only some sectors or institutions of these economies through the effects of production diversification (York, 2004). Hence, Langhelle notes, “... ecological modernization has no established relationship either to the global environmental problems or to social justice. There are, in fact, no explicit references or connections at all to the global dimensions of developmental and distributional problems” (2000: p. 309). Wallis refers succinctly to this aspect of ecological modernization: "the soundness of the part is overridden by the unsoundness of the whole” (2001: p. 138, emphasis in original).

These eco-socialist perspectives may be helpful to infer that the globalizing private agri-food standardization is being set primarily for a handful of affluent capitalist nations and business elites in the North to accumulate wealth by managing the very risks they have produced on the global scale (e.g., chemical pollution). This is done at the expense of reviving the classical problem of class, inequality, and North-South dependency in its updated forms.

\section{Reconciling Safety and Fairness in Global Agri-Food Standardization}

How to achieve compatibility between safety and fairness remains a pressing yet difficult question on both ethical and technical dimensions of global agri-food standardization. Private food safety standards such as GlobalGAP have placed emphasis on upgrading the social and technological organization to ensure the safety of food and employed producers yet at the cost of rising expenditures and exclusion of less powerful stakeholders in the upstream supply chain. Alternative approaches do exist, however, which place more weight on the inclusion of a large number of small-scale producers.

\section{Thailand's Q-GAP Programmeme}

Take the example of Thailand's Q-GAP (Q denotes “quality"). This is one of the public GAP programmes that the governments in ASEAN (the Association of South-East Asian Nations) nations have developed since around the turn of the millennium. These public GAP schemes in the region, including Indon-GAP (Indonesia), Singapore GAP-VF, Malaysian SALM, Q-GAP (Thailand), and Philippine-GAP, should not be conflated by private-driven national standards that have benchmarked with GlobalGAP, such as ChileGAP and ThaiGAP (Asia Pacific Economic Cooperation, 2006).

Thai government established Q-GAP in 2003 and began to implement it in 2004. Designed primarily as a public food safety certification programme, the uniqueness of the programme lies in the organizational system: producers without any membership of a producer organization but applying for the public GAP programme are organized into a group of twenty members called farmer field schools (FFS) in order to facilitate farmerto-farmer extension. Thai government provides technical assistance related to training, certification, and accreditation for 
producers basically for free. As a result, by 2010 approximately 212,000 farm households had been certified of 128 fresh fruits and vegetables over a crop area of 225,000 hectares (equivalent to $3.7 \%$ of Thailand's farm households and $1.2 \%$ of the nation's arable and permanent cropland area) (Schreinemachers et al., 2012). The public accomplishment of fairness regarding the massive inclusion of small-scale producers in Thailand's QGAP becomes apparent as it is compared with GlobalGAP which has certified about 102,000 producers in 108 countries during the last decade of its implementation (GlobalGAP, 2010).

Recent studies on the implementation of Q-GAP in Thailand inform, however, that the safety assurance system deployed in Q-GAP, along with other attributes concerned with good agricultural practices, is far from thorough as compared with that prepared in private GAP schemes such as GlobalGAP. Comparing the intensity of pesticide use between 45 Q-GAP certified and 245 non-certified fruit and vegetable growers in a watershed of northern Thailand, Schreinemachers et al. (2012) found that there are no significant statistical differences between those types of growers with regard to the amount of pesticides used, methods of pest control, and pesticide handling. In violation with official Q-GAP guidelines, farmers were not provided with training in integrated pest management; the auditor informed the farmers about the audit in advance; and the auditing was done once instead of three times as prescribed, taking as little as five minutes per farm. Studying 67 Q-GAP certified pummelo growers in two communities of northeastern Thailand, Amekawa (In Press) observed that about half of the interviewed producers could not correctly identify the rationale of the Q-GAP program. The majority of the growers did not regularly practice record keeping either. Moreover, most of the growers who reported a reduction in their pesticide use in years after they began to participate in Q-GAP attributed it to the growth stage of pummelo rather than the effect of Q-GAP certification.

These studies suggest that it is not difficult for Q-GAP applicant producers to pass the public certification without changing their conventional, agrochemical-driven production practices. This laxness is reflected in the compliance criteria: for vegetable and fruit farmers to get certified, while Q-GAP only requires $51 \%$ of compliance for 84 total control points, GlobalGAP requires $100 \%$ of compliance for 74 points and $90 \%$ for 125 points, with the total required control points of 236 (including 37 recommended points) (GlobalGAP, 2007). The relative looseness of Q-GAP in compliance criteria would not allow it to capture the equal credibility as enjoyed in international markets of the private GAP certified products.

\section{Policies and Practices Needed to Reconcile Safety and Fairness in Public GAP Approaches}

As shown, reconciling safety and fairness in global agri-food standardization is not an easy balancing act. Starting low and gradually raising the bar of food safety assurance while training and certifying an expanding body of smallholder producers remains a possible option, however. Such a gradual process would be facilitated if the following policies and practices are to be accompanied.

Regarding the core government policy reformulation:

- In the initial phase of the introduction of a public GAP scheme, it is important to limit the number of participant producers while taking sufficient time and allocating enough resources to build the firm training basis for the auditing body as well as the growers being audited. Achieving social justice in certification by allowing the participation of a fair number of resource poor producers is of critical importance in the context of the developing world. For the short term, however, appropriate training of professional/volunteer auditors and participant producers should be given a priority to maintain the long term goal of ensuring the integrity of the national policy and its domestic and international credibility. The importance of training is enormous given the current state of limited producers' understanding of GAP requirements, poor record keeping, and low motivation/incentives to implement GAP concepts. The training process should go hand in hand with upgrading the stringency in compliance requirements of the GAP standards.

- Public GAP standards should pay greater attention to the effects of agrochemical hazards on producers' health and the environment. The present system of the regulation focuses almost exclusively on the issues of food safety. The emphasis of pesticide control is placed on the use during the period immediately prior to harvest. When the produce is yet immature, the amount of pesticides used can be uncontrolled and thus significant, therefore, causing considerable negative repercussions on producers' health and the environment. Lack of monitoring on the methods of protection of pesticide applicators from pesticide hazards remains a serious problem. Contamination of pesticides in the environment is posing threats to local people who, for instance, eat fish or insects caught locally or who play in chemical-polluted ponds or rivers. In public GAP regulations, therefore, stronger focus needs to be placed on producers' health and the environment.

- Public universities with department of agriculture/ecology are to be encouraged to establish crop/context specific IPM methods that are low cost, effective, and feasible for local producers involved in public GAP certification. The role of university in both developing and developed countries has been focused narrowly on industrial agriculture technologies related to Green Revolution and biotechnology. University has a potential to develop agroecologically-oriented IPM methods, however. The potential can materialize if the government places public universities in line with the public GAP programme. The process of dissemination of developed IPM methods should involve collaboration with local public extension and producer groups.

Regarding the promotion of partnership between public and other sectors:

- Public GAP enterprises can be developed to produce pesticide-free or chemical-free commodities. The production can gain integrity and efficiency based on the mutual learning through FFS activities. The products can be exported through international fair trade whereby minimum farm-gate prices and price premiums are guaranteed. By engaging domestic exporters, foreign importers, and retailers in this potentially profitable business model, the GAP enterprises could be developed as a viable model of international privatecivic partnership.

- With respect to mainstream domestic marketing, policy planners could add to a public GAP programme some versions of geographical indications (GIs) that are developed through direct involvement by local governments and communities. GIs place emphasis on specific place or territory 
of which specific cultural, social, and environmental contexts come to the fore of production and marketing. Unique regional or local agroecological contexts of production and adopted environmental innovations such as locally invented EM (denoting "effective microorganisms"-a compost made up of fermented fruit, vegetables, food residues, and others using microbial enzymatic activity) may make some FFV products unique local/regional brands differentiated through a public GAP scheme. Certified groups of producers may commercially benefit from certification through increased prestige of their products or a premium granted to them, thus offsetting the externalities accruing in practising alternative production. It is worth noting that this direction towards GIs is consistent with the ongoing trend of rural decentralization in many development countries.

- A multiplication of FFS initiatives on irrigated rice fields under the public GAP framework could improve the agroecology of rice farming with relatively low costs. Evidence suggests that rice farming in irrigated areas is advantageous for lowering the use of insecticides and increasing yields without significant economic losses, investments in bio-control production, and learning costs related to monitoring techniques (Way \& van Emden, 2000). An increase in IPM-oriented FFS activities integrated in a public GAP programme will thus contribute to the livelihoods of resource poor farmers through the improved efficiency in household production, sale, and financing.

- In the domestic marketing of public GAP certified products, government agencies in charge of agricultural marketing should provide in close association with local producer groups institutional venues for those products to be directed more effectively to domestic supermarkets. This will help to limit the current activities of private intermediary dealers in dictating the local agricultural marketing to the disadvantage of resource poor producers. By selling public GAP certified products to supermarkets, the producers should be enabled to receive higher farm gate prices than non-GAP certified products.

\section{Conclusion}

This paper has examined issues of contradictions between food safety and fairness and their reconciliation with regard to private and public GAP standards. In response to rising consumer concerns about food safety, private GAP standards such as GlobalGAP and other programmes benchmarked with it have emerged since the late 1990s as a key mechanism of global trade. Their relatively high levels of stringency in compliance and required costs pose a potential that they not only work against low income countries as a trade barrier for export, but also prohibit resource poor farmers and small-scale exporters to participate in the lucrative sector of global value chains. Currently, therefore, private GAP approaches exhibit the tendency to prioritize food safety over the concerns of social inclusion.

On the other hand, since the turn of the millennium public GAP standards have come into force in ASEAN countries. Due to their relatively low levels of stringency in compliance and required costs, these GAP standards embrace a potential to encourage a broad cohort of small-scale, resource poor producers to be involved in mainstream markets, both domestic and international. Public GAP approaches may thus be more capable of ensuring fairness at some sacrifice of food safety and quality.

In the current configuration of the global GAP regime, reconciliation of safety and fairness is a necessary yet painstaking task. Public GAP standards would be better qualified to pursue the middle ground than private GAP standards because of the interests of the governments in national public welfare; the for-profit rationalization tendency of private GAP programmes is in stark opposition to meeting the social justice goal of including many resource poor producers in certification. It is important for the governments involved in public GAP programmes to take sufficient time to increase the number of certified producers by gradually raising the level of stringency of control points. In doing so, it is critical for them, as suggested by Schreinemachers et al. (2012), to allocate adequate resources for strengthening the base of auditing institutions and local extension networks involved, thus moving the programmes beyond the current focus on residue testing.

\section{REFERENCES}

Amekawa, Y. (In Press). Can public GAP approach ensure safety and fairness? A comparative study of Q-GAP in Thailand. Journal of Peasant Studies.

Altieri, M. A., \& Nicholls, C. I. (2005). Agroecology and the search for a truly sustainable agriculture. Nairobi: United Nations Environment Programme.

Asia Pacific Economic Cooperation (APEC) (2006). Proceeding of the capacity building seminar on good agricultural practices for APEC developing economies. URL (last checked October 2010). http://publications.apec.org/publication-detail.php?pub_id=281

Beck, U. (1992). Risk society: Towards a new modernity. London: SAGE Publications Ltd.

Barham, E. (2002). Towards a theory of values-based labeling. Agriculture and Human Values, 19, 349-360. doi:10.1023/A:1021152403919

Blowers, A. (1997). Environmental policy: Ecological modernisation or the risk society? Urban Studies, 34, 845-871. doi:10.1080/0042098975853

Burkett, P. (2002). Nature and value: A discussion. Science \& Society, 67, 452-462. doi:10.1521/siso.67.4.452.25333

Buttel, F. H. (2000). Ecological modernization as social theory. Geoforum, 31, 57-65. doi:10.1016/S0016-7185(99)00044-5

Busch, L., \& Bain, C. (2004). New! Improved? The transformation of the global agrifood system, Rural Sociology, 69, 321-346. doi:10.1526/0036011041730527

Codron, J.-M., Giraud-Héraud, E., \& Soler, L.-G. (2005). Minimum quality standards, premium private labels, and European meat and fresh produce retailing. Food Policy, 30, 270-283. doi:10.1016/j.foodpol.2005.05.004

Cohen, M. J., (1997). Risk society and ecological modernisation: Alternative visions for post-industrial nations, Futures, 29, 105-119. doi:10.1016/S0016-3287(96)00071-7

Fisher, D., \& Freudenburg, W. (2001). Ecological modernization and its critics: Assessing the past and looking toward the future. Society and Natural Resources, 14, 701-709. doi:10.1080/08941920152524891

Foster, J. B. (2000). Marx's ecology: Materialism and nature. New York: Monthly Review Press.

GlobalGAP (2007). Control points and control criteria: Integrated farm assurance-English versions v.3-2. URL (last checked October 2009). http://transition.usaid.gov/our_work/environment/compliance/ane/wo rkshops/Jordan2007/day2/K/AllFarmBase.pdf

GlobalGAP (2010). GlobalGAP. Annual report 2010. URL (last checked September 2011).

http://issuu.com/globalgap/docs/globalg.a.p_annual_report_2010/1

Graffham, A., Karehu, E., \& MacGregor, J. (2007). Impact of EurepGAP on small-scale vegetable growers in Kenya. URL (last checked 


\section{Y. AMEKAWA}

October 2009).

http://www.agrifoodstandards.net/en/filemanager/active?fid=83

Graffham, A., \& MacGregor, J. (2007). Impact of EurepGAP on smallscale vegetable growers in Zambia. URL (last checked October 2009). http://www.agrifoodstandards.net/resources/

Hatanaka, M., Bain, C., \& Busch, L. (2005). Third-party certification in the global agrifood system. Food Policy, 30, 354-369. doi:10.1016/j.foodpol.2005.05.006

Henson, S. J., \& Reardon, T. (2005). Private agri-food standards: Implications for food policy and the agri-food system. Food Policy, 30, 241-253. doi:10.1016/j.foodpol.2005.05.002

Kleih, U., Ssango, F., Kyazze, F., Graffham, A., \& MacGregor, J. (2007). Impact of EurepGAP on small-scale fruit and vegetable growers in Uganda. URL (last checked March 2009).

http://www.agrifoodstandards.net/resources/global/fresh_insights_10 _impact_of_euregap_on_small_scale_vegetable_growers_in_uganda

Langhelle, O. (2000). Why ecological modernization and sustainable development should not be conflated. Journal of Environmental Policy \& Planning, 2, 303-322.

Löwy, M. (2002). From Marx to Ecosocialism. Capitalism, Nature, Socialism, 13, 121-133. doi:10.1080/104557502101245413

Mol, A. P. J., \& Sonnenfeld, D. A. (2000). Ecological modernization around the world: An introduction. Environmental Politics, 9, 3-16.

Murray, D. L., \& Raynolds, L. (2000). Alternative trade in bananas: Obstacles and opportunities for progressive social change in the global economy. Agriculture and Human Values, 17, 65-74. doi:10.1023/A:1007628709393

O’Connor, J. (1998). Natural causes. New York: Guilford.

Okello, J. J., \& Swinton, S. M. (2007). Compliance with international food safety standards in Kenya's green bean industry: Comparison of a small- and a large-scale farm producing for export. Review of Agricultural Economics, 29, 269-285. doi:10.1111/j.1467-9353.2006.00342.x

Rosset, P. M., \& Altieri, M. A. (1997). Agroecology versus input substitution: A fundamental contradiction of sustainable agriculture. Society \& Natural Resources, 10, 283-295. doi:10.1080/08941929709381027

Schreinemachers, P., Schad, I., Tipraqsa, P., Williams, P. M., Neef, A., Riwthong, S., Sangchan, W., \& Grovermann, C. (2012). Can public GAP standards reduce agricultural pesticide use? The case of fruit and vegetable farming in northern Thailand. Agriculture \& Human Values, 29, 519-529.

Temu, A. E., \& Marwa, N. W. (2007). Changes in the governance of global value chains of fresh fruits and vegetables: Opportunities and challenges for producers in Sub-Saharan Africa. Geneva: South Centre.

Wallis, V. (2001). Toward ecological socialism. Capitalism, Nature, Socialism, 1, 127-145.

Way, M. J., \& van Emden, H. F. (2000). Integrated pest management in practice: Pathways towards successful application. Crop Protection, 19, 81-103. 